\title{
Complications of endoscopic retrograde cholangiopancreatography. A study in a small ERCP unit
}

\author{
J. García-Cano Lizcano, J. A. González Martín, J. Morillas Ariño and A. Pérez Sola \\ Service of Digestive Diseases. Hospital Virgen de la Luz. Cuenca, Spain
}

\begin{abstract}
Backgrounds and aim: endoscopic retrograde cholangiopancreatography (ERCP) is an established procedure to drain the biliary and pancreatic ducts. Nevertheless, there are complications which seem to be more common in centers performing less than 200 ERCPs per year. Sometimes, however, due to the distribution of health resources, it is necessary to perform this technique in centers with a smaller number of procedures. We present the experience of ERCP-related complications in a small unit.

Material and methods: this is a retrospective study on prospective data recorded during six years (1997-2002). In this period, two endoscopists working together performed 507 ERCPs, which yields an approximately average of 84 procedures per year.

Results: in 507 ERCPs performed during this period of time, 55 complications arose (10.85\%), and four patients died $(0.79 \%)$ as a consequence of the procedure. There were 28 pancreatitis (5.5\%), eight post-sphincterotomy bleeding events (1.6\%), seven bilioduodenal perforations (1.4\%), eight sepsis episodes of biliary origin (1.6\%), and other 4 different complications. There were $418(82.4 \%)$ successful ERCPs -either diagnostic or therapeutic-, which gave rise to 46 (11\%) complications. There were 89 (17.6\%) failed diagnostic or therapeutic ERCPs, which gave rise to $9(10.11 \%)$ complications ( $p=0.8$ between both groups). Thirty five $(7 \%)$ ERCPs were exclusively diagnostic and caused $6(17 \%)$ complications. The 187 procedures performed for coledocholithiasis originated $14(7.4 \%)$ complications, and represented the group with the lowest morbidity rate $(p=0.04)$.

Conclusions: the complications rate in our center is within the range of reported figures. ERCPs performed for choledocolithiasis was associated with the lowest complications rate. The risk-benefit ratio in the anticipated, purely diagnostic ERCP must be carefully weighed due to its morbidity.
\end{abstract}

Key words: ERCP complications.

Recibido: 20-01-03.

Aceptado: 03-09-03.

Correspondencia: J. García-Cano Lizcano. Residencial Los Alfares, bloque 4, 6 ${ }^{\circ}$ D. 16002 Cuenca. e-mail: jgarciacano@teleline.es
García-Cano Lizcano J, González Martín JA, Morillas Ariño J, Pérez Sola A. Complications of endoscopic retrograde cholangiopancreatography. A study in a small ERCP unit. Rev Esp Enferm Dig 2004; 96: 163-173.

\section{INTRODUCTION}

Endoscopic retrograde cholangiopancreatography $(\mathrm{ERCP})$ is a very effective procedure to drain both the biliary and pancreatic ducts (1). Nowadays, available methods to image the pancreatobiliary system, specially magnetic resonance cholangiopancratography (MRCP), have turned ERCP into an eminently therapeutic procedure.

Gaining access to the bile and pancreatic ducts, sphincterotomy, choledocholithiasis extraction, and biliary and pancreatic stent insertion are the more difficult procedures in digestive endoscopy (2).

The complexity of the procedure entails a morbidity that seems to be higher in centers performing few explorations. Though no unanimously accepted criteria exist, minimal standards have been fixed in 200 ERCPs per year (3), more than one sphincterotomy every week (4), or at least 40 sphincterotomies per year for each endoscopist (5).

Nevertheless, the distribution and access of patients to health resources can generate the need to perform this technique in hospitals in which a limited volume of procedures is annually expected. We present our experience regarding ERCP-related complications in a small unit.

\section{MATERIAL AND METHODS}

During a 6-year period (1997-2002) two endoscopists (JGL and JGM), working together, performed 507 ERCPs. 
This means an approximate average of 84 procedures per year. In alternate explorations, each of them acted as first or main endoscopist, while the other helped him as second endoscopist.

Patients were under conscious sedation with meperidine and diazepam or midazolam, administered by endoscopists themselves. Overall, the same team of nurses and endoscopy assistants was present at each exploration. Heart rate and oxygen blood saturation were monitored during ERCP. Oxygen was administered to patients by means of a nasal cannula. ERCPs were performed in a room with fluoroscopy facilities within the radiology department. All patients gave their informed consent for the procedure after receiving adequate medical information.

Therapeutic duodenoscopes with a working channel of $4.2 \mathrm{~mm}$ were used. Vater's papilla cannulation, sphincterotomy, dilatation, stent insertion, and other ERCP maneuvers were performed as previously described (6-8). When cannulation failed after using standard cannulae or sphincterotomes, a tapered-tip sphincterotome loaded with a 0.025 in guidewire proved very useful (9), and was used before performing a precut.

A diagnostic failure was considered when the desired duct could not be cannulated. Therapeutic failure was defined as the lack of effective endoscopic treatment (in general, an adequate duct drainage when necessary). Procedures for choledocolithiasis that could not be completed were not considered a therapeutic failure, if a stent was inserted to maintain a temporary drainage.

Odditis was diagnosed by means of the available clinical, analytical, and cholangiographic data.

All ERCPs were performed on an in-patient regime. Patients remained at hospital at least for the night after the procedure. In the following days, the occurrence of complications was ruled out. Complications were graded according to a 1991 consensus (10).

Data relative to procedures and complications were gathered in a prospective way, though the global analysis was performed in a retrospective way. Statistical analyses were carried out by using the Rsigma software program. A $p$ value below 0.05 was considered significant.

\section{RESULTS}

Five hundred and seven ERCPs were performed. There were $55(10.85 \%)$ complications in 52 patients (Table I). There were $28(5.5 \%)$ acute pancreatitis cases, most of them graded as mild to moderate. Only four of them needed admission to an Intensive Care Unit (ICU). There was no mortality related to pancreatitis.

Eight (1.6\%) post-sphincterotomy hemorrhages occurred. All of them needed endoscopic sclerotherapy on the bleeding source and blood transfusion. Two patients needed 5 or more unit of packed red blood cells, and these complications were accordingly graded as severe. Neither surgery nor therapeutic angiography were needed.

A duodenal perforation took place far from the papillary area in three patients $(0.6 \%)$. The first one happened in the afferent loop of a Billroth II gastrectomy. The second perforation developed in a stenosed and deformed peptic duodenal bulb. The third one was secondary to a $15 \mathrm{~cm}$-long biliary plastic stent previously inserted to treat a benign stricture, which perforated the duodenum. All patients underwent surgery and no mortality occurred as a consequence of the perforation.

In three women perforation took place within the papillary area $(0.6 \%)$. A false route developed in a patient when

Table I. Complications reported for 507 ERCPs. Three patients had two complications (two patients had pancreatitis and cholangitis, and one patient pancreatitis and hemorrhage)

\begin{tabular}{|c|c|c|c|c|c|}
\hline Type of complication & Total (\%) & Mild to moderate & Surgery & $\begin{array}{l}I C U \\
(* *)\end{array}$ & $\begin{array}{c}\text { Deaths } \\
(* * *)\end{array}$ \\
\hline Pancreatitis & $28(5.5 \%)$ & 24 & - & 4 & - \\
\hline Papillary area perforation & $3(0.6 \%)$ & 2 & - & - & 1 \\
\hline Duodenal perforation & $3(0.6 \%)$ & - & 3 & - & - \\
\hline Biliary perforation & $1(0.2 \%)$ & - & - & - & 1 \\
\hline Zenker's diverticulum perforation & $1(0.2 \%)$ & - & 1 & - & - \\
\hline Post-sphincterotomy hemorrhage & $8(1.6 \%)$ & $6^{*}$ & - & - & - \\
\hline Cholangitis & $6(1.3 \%)$ & 5 & - & 1 & - \\
\hline Cholecystitis & $2(0.4 \%)$ & 1 & - & - & 1 \\
\hline Cardio-respiratory arrest & $1(0.2 \%)$ & - & - & - & 1 \\
\hline Pulmonary edema & $1(0.2 \%)$ & - & - & 1 & - \\
\hline Intrapancreatic stent fracture & $1(0.2 \%)$ & - & 1 & - & - \\
\hline Total & $55(10.85 \%)$ & $38 *(7.49 \%)$ & $5(0.98 \%)$ & $6(1.18 \%)$ & $4(0.79 \%)$ \\
\hline
\end{tabular}

$\left.{ }^{*}\right)$ Two patients needed transfusion with more than 5 red-blood-cell packets. Therefore, these bleedings were considered a severe complication. To obtain 55 complications, these two patients with severe hemorrhage have to be added to the six with mild-moderate bleeding. Percentages are expressed for 507 ERCPs.

$(* \star)$ Patients who needed admission to an Intensive Care Unit (ICU). Patients who initially underwent surgery for a complication and were then admitted to an ICU are not included.

$(* * *)$ None of the patients who died underwent surgery or were admitted to an ICU. 
trying to recannulate the bile duct after a sphincterotomy had been performed. A guidewire had not been left in place, and a retroperitoneal contrast injection occurred. In another patient, a perforation was induced by a large sphincterotomy in the setting of an intradiverticular papilla. These two patients recovered satisfactorily with medical treatment. The third of these perforations took place in an elderly patient with cholangitis. This perforation followed a precut and the patient died.

A patient with a complex hilar neoplasm presented with a biliary perforation probably related to dilatation, before stent insertion. The patient developed an abdominal abscess. His general condition adviced that no type of aggressive treatment be attempted, and the patient died a few days later. Therefore, bilioduodenal perforations were $7(1.4 \%)$ in all.

A previously unknown Zenker's diverticulum was perforated in another patient. The diagnosis was immediately reached on observing mediastinal structures. It was also confirmed by water-soluble contrast extravasation from the esophagus. The patient underwent surgery and finally recovered after a complicated postoperative period.

Six $(1.2 \%)$ patients developed cholangitis. In five of such cases, it was secondary to retained choledocholithiasis after ERCP, or to plastic biliary stents inserted in hilar tumors. They all evolved satisfactorily with medical treatment. The remaining cholangitis happened in a patient who was later diagnosed of leukemia, and needed admission to an ICU.

Two patients developed cholecystitis. One of them, a patient with a neoplasm of the head of the pancreas in whom a plastic biliary stent had been previously inserted, died. Therefore, there were $8(1.6 \%)$ sepsis cases of biliary origin (cholangitis and cholecystitis).

An elderly patient in whom an ERCP was performed for cholangitis died after presenting a cardio-respiratory arrest on arriving at his ward after the procedure. This complication may be probably related to sedative medication during the endoscopic procedure. Another patient with ischemic heart disease developed a few hours after the endoscopic procedure congestive heart failure and pulmonary edema. He recovered after ten days in an ICU.

Finally, a $12 \mathrm{~cm}$-long pancreatic stent broke within the pancreas. It had been inserted to treat a pleuro-pancreatic fistula in a patient with chronic pancreatitis. The distal part of the stent remained within Wirsung's duct after having tried to extract it once the fistula had cured. The patient needed a distal pancreatectomy following unsuccessful attempts at endoscopic extraction.

Only $17 / 55$ complications were severe (31\%), which in the whole series represents $17 / 507$ (3.3\%) severe complications. Thus, the majority were graded as mild to moderate and patients recovered with medical treatment. Four patients $(0.79 \%)$ died.

\begin{tabular}{|c|c|c|c|}
\hline Type of procedure & $\begin{array}{c}\text { Number of } \\
\text { patients in } \\
\text { each group (\%) }\end{array}$ & $\begin{array}{c}\text { Complications } \\
(\%)\end{array}$ & $p$ value (1) \\
\hline $\begin{array}{l}\text { Failed papillary access } \\
\text { or cannulation }\end{array}$ & $61 / 507(12 \%)$ & $6 / 61(9.8 \%)$ & $p=0.7$ \\
\hline $\begin{array}{l}\text { Therapeutic failure after } \\
\text { successful cannulation }\end{array}$ & $28 / 446(6.2 \%)$ & $3 / 28(10.7 \%)$ & $p=0.9$ \\
\hline $\begin{array}{l}\text { Exclusively diagnostic with } \\
\text { no need for therapy }\end{array}$ & $35 / 418(8.3 \%)$ & $6 / 35(17 \%)$ & $p=0.2$ \\
\hline $\begin{array}{l}\text { Choledocholithiasis and } \\
\text { biliary sludge treatment }\end{array}$ & $187 / 418(44.7 \%)$ & $14 / 187(7.4 \%)$ & $p=0.04 * *$ \\
\hline Malignant biliary drainage & $72 / 418(17.22 \%)$ & $10 / 72(13.8 \%)$ & $\mathrm{p}=0.4$ \\
\hline $\begin{array}{l}\text { Biliary sphincterotomy } \\
\text { for passed choledocho- } \\
\text { lithiasis and odditis }\end{array}$ & $83 / 418(19.8 \%)$ & $12 / 83(14.5 \%)$ & $p=0.2$ \\
\hline $\begin{array}{l}\text { Mirizzi's syndrome and } \\
\text { other benign stricture } \\
\text { treatment }\end{array}$ & $35 / 418(8.3 \%)$ & $3 / 35(8.5 \%)$ & $p=0.6$ \\
\hline Pancreatic therapy & $6 / 418(1.4 \%)$ & $1 / 6(16.6 \%)$ & $p=0.6$ \\
\hline Total & 507 & $55 / 507(10.85 \%)$ & \\
\hline
\end{tabular}

(1) Statistical comparison of complications between each group and the rest of the series.

$(* *)$ Choledocholithiasis treatment had significantly fewer complications than the rest of the series.

All ERCP procedures were allocated to 8 groups (Table II): exclusively diagnostic procedures, therapeutic procedures, and failed procedures. It is remarkable that the $187 / 418(44.7 \%)$ ERCPs performed to extract choledocholithiasis made up the group with the lowest complications rate $(14 / 187-7.4 \%-)$, and the only group with significantly less morbidity $(\mathrm{p}=0.04)$ when compared to the rest of the series.

The ERCP group that needed no therapeutic measures (exclusively diagnostic) was the one that had more complications: $6 / 35(17 \%)$. Nevertheless, this figure did not reach statistical significance when compared to the rest of the series.

No statistical difference was either found $(\mathrm{p}=0.8)$ between the 46 (11\%) complications in the $418 / 507$ $(82.4 \%)$ ERCPs that were successfully diagnostic and therapeutic (when necessary), and the 9 (10.11\%) complications in $89 / 507(17.6 \%)$ ERCPs with diagnostic or therapeutic failure.

As a whole, a precut was used in $63 / 507$ (12.4\%) of ERCPs. There were no differences in use between the various ERCP groups. Logically, access to the bile duct was prevented in the failed ERCP group. There were 8/63 (12.7\%) complications, which does not reach significance when compared to ERCPs in which precut was not used. 


\section{DISCUSSION}

ERCP is the most difficult technique in digestive endoscopy. Complications occur approximately in $10 \%$ of cases, and mortality is about $1 \%$ (2). This is the range within which figures from a great number of published series lay (Table III). Overall, data from our study, with $10.85 \%$ of complications and a mortality of $0.79 \%$, fit also in previously reported figures.

The four typical complications of ERCP are: acute pancreatitis, post-sphincterotomy bleeding, sepsis of biliary origin (cholangitis and cholecystitis), and perforation, either of the papillary area for sphincterotomy, or duodenal (far from the papillary area) for endoscopy or biliary stents. In our study, we found a pancreatitis rate of $5.5 \%$, a hemorrhage rate of $1.6 \%$, a rate of of bilioduodenal perforation of $1.4 \%$, and a rate of biliary sepsis of $1.6 \%$. These figures are also comparable to those in other studies (Table IV). There are, in addition, other rarer and less typical adverse effects of ERCP. In our case, there was a Zenker's diverticulum perforation, intrapancreatic fracture of a plastic stent, cardio-respiratory arrest -probably related to sedation- and pulmonary edema a few hours after ERCP. We considered this complication to be related to the endoscopic intervention since myocardial blood flow reduction has been described during ERCP (29).

Anyhow, the real percentage of complications is probably higher than that in published series. The great majority of studies define ERCP complications according to a 1991 consensus (10). According to these criteria, and with regard to post-sphincterotomy hemorrhage, for instance, this begins as a mild complication when hemoglobin drops more than 2 grams. Bleeding during the endoscopic procedure, with no hemogram decreases, is not considered a complication. Nevertheless, if hemostatic measures must be taken to stop a hemorrhage episode, ERCP complexity can increase enormously, even though this is not reflected as a complication.

With regard to acute pancreatitis, the usual definition is an at least three-fold increase of serum amylase for more than 24 hours, together with abdominal pain, which needs hospitalization. If ERCP is performed on an outpatient regime and the published series is retrospective, patients may complaint with mild abdominal pain at home, which really corresponds to a mild pancreatitis. This attack will remains undiagnosed and, therefore, unreported. Baillie reported (30) that the rate of ERCP complications at his center increased by $50 \%$ after a prospective study was performed by means of a telephonic

Table III. Morbidity and mortality in some general ERCP series

\begin{tabular}{|c|c|c|c|c|c|c|c|}
\hline $\begin{array}{l}\text { Author } \\
\text { (reference) }\end{array}$ & Year & Country & $\begin{array}{l}\text { Single center or } \\
\text { multicenter }\end{array}$ & $\begin{array}{r}\text { Number of } \\
\text { ERCPS }\end{array}$ & $\%$ complications & $\%$ mortality & Observations \\
\hline Zimmon (11) & 1975 & USA & Single & 300 & 5 & 0 & Only diagnostic ERCP \\
\hline Bilbao (12) & 1976 & USA & Multicentre & 10,435 & 3 & 0.2 & Only diagnostic ERCP \\
\hline Moreira (14) & 1982 & Spain & Single & 500 & 2.8 & 0.2 & $\begin{array}{l}\text { The majority only } \\
\text { diagnostic ERCP }\end{array}$ \\
\hline Elizondo (15) & 1989 & Mexico & Single & 500 & 5.6 & 0.8 & \\
\hline Freeman (4) & 1996 & $\begin{array}{l}\text { USA and } \\
\text { Canada }\end{array}$ & Multicentre & 2347 & 9.8 & 0.4 & $\begin{array}{l}\text { Only ERCP with } \\
\text { sphincterotomy }\end{array}$ \\
\hline Anh (16) & 1997 & Vietnam & Single & 318 & 7.2 & 0.3 & \\
\hline Loperfido (3) & 1998 & Italy & Multicentre & 2,769 & 4 & 0.4 & \\
\hline Ciriza (17) & 1999 & Spain & Single & 425 & 8.6 & 1.6 & \\
\hline Halme (18) & 1999 & Finland & Single & 813 & 9.1 & 0.9 & $\begin{array}{l}\text { Only sphincterotomy } \\
\text { complications }\end{array}$ \\
\hline Mala (20) & 2000 & Norway & Single & 567 & 1.2 & 0.8 & $\begin{array}{l}\text { Only severe } \\
\text { complications reported }\end{array}$ \\
\hline Gómez-Ponce (21) & 2000 & Peru & Single & 202 & 5.9 & 0 & \\
\hline Tzovaras (22) & 2000 & Australia & Single & 372 & 4.3 & 1.3 & \\
\hline Masci (23) & 2001 & Italy & Multicentre & 2,462 & 4.95 & 0.12 & \\
\hline Farrell (24) & 2002 & Ireland & Single & 1,758 & 3.5 & 0.35 & \\
\hline Vandervoort (25) & 2002 & USA & Single & 1,223 & 11.2 & 0.16 & \\
\hline Suissa (26) & 2002 & Israel & Single & 722 & 10.5 & 0.5 & \\
\hline Barthet (27) & 2002 & France & Single & 658 & 7.7 & 0.9 & $\begin{array}{l}\text { Only ERCP with } \\
\text { sphincterotomy }\end{array}$ \\
\hline García-Cano (*) & 2003 & Spain & Single & 507 & 10.85 & 0.79 & \\
\hline
\end{tabular}


Table IV. Specified complications in reported general prospective series of ERCP. Comparisons are difficult. Some series only refer complications related to sphincterotomy. In the series by Loperfido, mild complications (especially pancreatitis) were not reported. Quoted complications do not represent the total number, since other less typical ERCP complications (like cardiopulmonary complications) are not reflected in this table

\begin{tabular}{|c|c|c|c|c|c|c|c|c|}
\hline $\begin{array}{l}\text { Author } \\
\text { (reference) }\end{array}$ & Year & $\begin{array}{l}\text { Complications/ } \\
\text { patients }\end{array}$ & Pancreatitis & Hemorrhage & $\begin{array}{c}\text { Biliary } \\
\text { sepsis (1) }\end{array}$ & Perforation & Mortality & Observations \\
\hline Freeman (4) & 1996 & $229 / 2,347(9.8 \%)$ & $127(5.4 \%)$ & $48(2 \%)$ & $35(1.5 \%)$ & $8(0.3 \%)$ & $10(0.4 \%)$ & Only sphincterotomies \\
\hline Rabenstein (28) & 2000 & $33 / 438(7.5 \%)$ & $19(4.3 \%)$ & $10(2.3 \%)$ & $4(0.9 \%)$ & 0 & $2(0.5 \%)$ & Only sphincterotomies \\
\hline Barthet (27) & 2002 & $74 / 1,159(6.3 \%)$ & $29(2.5 \%)$ & $9(0.7 \%)$ & $20(1.7 \%)$ & $26(2.2 \%)$ & $6(0.5 \%)$ & General ERCP series \\
\hline Barthet (27) & 2002 & $51 / 658(7.7 \%)$ & $23(3.5 \%)$ & $8(1.2 \%)$ & $8(1.2 \%)$ & $12(1.8 \%)$ & $6(0.9 \%)$ & $\begin{array}{l}\text { Sphincterotomy } \\
\text { complications from the } \\
\text { above series }\end{array}$ \\
\hline
\end{tabular}

(1) Biliary sepsis refers to cholangitis and cholecystitis.

survey within 30 days following the procedure. Acute pancreatitis was the most frequent complication discovered.

Besides, prospective multicentre series -like that of Masci (23)- find fewer complications when compared to single-centre serie -as that of Vandervoort (25) for instance. Probably, in multicentre series some mild complications may be missed out. Otherwise, these are most frequently reported in all series.

Another aspect that must be kept in mind when analyzing these studies is what we may call "the philosophy of self-imputed complications". For example, in papers in which drugs are studied for the prevention of postERCP pancreatitis, the frequency of this complication in the control group is higher than in usual series (31).

ERCP is a very complex procedure which cannot be performed by all endoscopists (32). Not only is necessary a long learning period, but also skills already acquired should be maintained by performing the procedure in a steady and usual manner. Ideally, few endoscopists should perform more ERCPs (2). Nevertheless, as in our center, the distribution of health resources does probably require that this technique be performed in hospitals not reaching 200 ERCPs per year (33).

Constant and regular dedication by a few persons may obtain acceptable results for ERCP in a small center (3436). In our unit, the two doctors who perform this technique are present in all procedures, in half of them acting as main endoscopists, and as assistant endoscopists in the other half. This concept, which has been clearly defined for surgical interventions, is not currently used in the endoscopic setting. We think that the complexity of endoscopic pancreatobiliary interventionism is such that, besides relying on a team made up of qualified nurses and endoscopy asisstants (which may often make a difference between success and failure) (37), the presence of at least two performing doctors is most advisable. Endoscopes and devices that are suitable and in good condition are another factor for success (38).

In our study, successful ERCPs had similar complications rates when compared to unsuccessful ERCPs. This is easily understandable. Fruitless, repeated attempts to cannulate the papilla induce pancreatitis, which is more serious when precut is used in an ineffective manner. Once cholangiography is performed, the inability to adequately drain an obstructed biliary tract results in cholangitis. Therefore, when an endoscopist faces an ERCP, he or she must have the highest possibility to obtain the expected results. To this end, ongoing technical improvement should be pursued in an attempt to overcome the minimal accepted success rate of $80 \%$ (39), using selfcriticism (40).

Finally, the only group in our study with significantly lower morbidity was that with choledocholithiasis treatment. Similar data were reported by Freeman (4) on patients in whom laparoscopy cholecistectomy had been performed. Diagnostic ERCPs had, therefore, more complications than ERCPs in which choledochal stones were extracted. This paradox underlines the need to avoid complications in patients who less need ERCP (41). When an exclusively diagnostic procedure is foreseen (42), it is necessary to carefully weigh the risk-benefit ratio the technique may bring. Under such circumstances, MRCP is probably the most useful method to be chosen nowadays (43).

\section{REFERENCES}

1. Summerfield JA. Biliary obstruction is best managed by endoscopists. Gut 1988; 29: 741-5.

2. Huibregtese K. Complications of endoscopic sphincterotomy and their prevention [editorial]. N Engl J Med 1996; 335: 961-3. 
3. Loperfido S, Angelini G, Benedetti G, Chilouri F, Costan F, De Berardinis $\mathrm{F}$, et al. Major early complications from diagnostic and therapeutic ERCP: a prospective multicenter study. Gastrointest Endosc 1998; 48: 501-10.

4. Freeman ML, Nelson DB, Sherman S, Haber GB, Herman ME, Dorsher PJ, et al. Complications of endoscopic biliary sphincterotomy. $\mathrm{N}$ Engl J Med 1996; 335: 909-18.

5. Rabenstein T, Schneider HT, Nicklas M, Ruppert T, Katalinic A, Hahn EG, et al. Impact of skill and experience of the endoscopist on the outcome of endoscopic sphincterotomy techniques. Gastrointest Endosc 1999; 50: 628-36.

6. Jacobson IM (editor). ERCP and its applications. Phialadelphia: Lippincott-Raven, 1998.

7. Martin DF, Tweedle D, Haboui NY. Clinical Practice of ERCP. Londres: Churchill Livingstone, 1998.

8. Topazian M (guest editor). Bile duct strictures. Techniques in Gastrointestinal Endoscopy 2002; vol. 4.

9. García-Cano Lizcano J, González Martín JA, Morillas Ariño MJ, Pérez Sola A. The Tapertome sphincterotome reduces the need of precut to cannulate the bile duct. [in Spanish]. Rev Esp Enferm Dig 2001; 93 (Supl. I): P-1.

10. Cotton PB, Lehman G, Vennes J, Geenen JE, Russell RC, Meyers WC, et al. Endoscopic sphincterotomy complications and their management: an attempt at consensus. Gastrointest Endosc 1991; 37: 383-93.

11. Zimmon DS, Falkenstein DB, Riccobono C, Aaron B. Complications of endoscopic retrograde cholangiopancreatography. Analysis of 300 consecutive cases. Gastroenterology 1975; 69: 303-9.

12. Bilbao MK, Dotter CT, Lee TG, Katon RM. Complications of endoscopic retrograde cholangiopancreatography (ERCP). A study of 10,000 cases. Gastroenterology 1976; 70: 314-20.

13. Soehendra N. Technique, difficulties and results of endoscopic retrograde cholangio-pancreatography (ERCP). Chirurg 1977; 48: 98-104.

14. Moreira Vicente VF, Meroño García E. Nuestra experiencia con la colangiopancreatografía retrógrada endoscópica (CPRE): 1977-1980. Rev Esp Enferm Dig 1982; 61: 202-17.

15. Elizondo J, Gallo S, Valdovinos MA, Paez R. Evaluación retrospectiva de 500 colangiopancreatografías endocópicas realizadas en el Instituto Nacional de la Nutrición "Salvador Zubirán". Rev Gastroenterol Mex 1989; 54: 19-26.

16. Anh LQ. Therapeutic endoscopy of the hepatobiliary and pancreatic system: a Vietnamese experience. JSLS 1997; 1: 345-8.

17. Ciriza C, Dajil S, Jiménez C, Urquiza O, Karpman G, García L, et al. Análisis de la práctica de CPRE durante cinco años en el Hospital del Bierzo. Rev Esp Enferm Dig 1999; 91: 693-7.

18. Halme L, Doepel M, von Numers H, Edgren J, Ahonen J. Complications of diagnostic and therapeutic ERCP. Ann Chir Gynaecol 1999; 88: 127-31.

19. Zinsser E, Hoffmann A, Will U, Koppe P, Bosseckert H. Success and complication rates of diagnostic and therapeutic endoscopic retrograde cholangiopancreatography -a prospective study. Z Gastroenterol 1999; 37: 707-13.

20. Mala T, Lunde OC, Nesbakken A, Aadland E, Stiris M. Endoscopic retrograde cholangiopancreatography -a 4-year retrospective study. Tidsskr Nor Laegeforen 2000; 120: 560-2.

21. Gómez Ponce RL. Complicaciones tempranas de las colangiopancreatografías retrógradas endoscópicas realizadas desde enero de 1998 a diciembre de 2000 en el Hospital Nacional Daniel Alcides Carrión de "El Callao", Perú. Rev Gastroenterol Peru 2002; 22: 33-43.

22. Tzovaras G, Shukla P, Kow L, Mounkley D, Wilson T, Toouli J. What are the risks of diagnostic and therapeutic endoscopic retrograde cholangiopancreatography? Aust N Z J Surg 2000; 70: 77882
23. Masci E, Toti G, Mariani A, Curioni S, Lomazzi A, Dinelli M, et al. Complications of diagnostic and therapeutic ERCP: a prospective multicenter study. Am J Gastroenterol 2001; 96: 417-23.

24. Farrell RJ, Mahmud N, Noonan N, Kelleher D, Keeling PW. Diagnostic and therapeutic ERCP: a large single centre's experience. Ir J Med Sci 2001; 170: 176-80.

25. Vandervoort J, Soetikno RM, Tham TCK, Wong RCK, Ferrari AP (Jr), Montes H, et al. Risk factors for complications after performance of ERCP.Gastrointest Endosc 2002; 56: 652-6.

26. Suissa A, Yassin K, Lavy A, Lachter J, Chermech I, Karavan A, et al. Outcome and early complications from ERCP: A prospective single-center study. Gastrointest Endosc 2002; 55: AB157.

27. Barthet M, Lesavre N, Desjeux A, Gasmi M, Berthezene P, Berdah $\mathrm{S}$, et al. Complications of endoscopic sphincterotomy: results from a single tertiary referral center. Endoscopy 2002; 34: 991-7.

28. Rabenstein T, Schneider HT, Bulling D, Nicklas M, Katalinic A, Hahn EGP, et al. Analysis of the risk factors associated with endoscopic sphincterotomy techniques: Preliminary results of a prospective study, with emphasis on the reduced risk of acute pancreatitis with low-dose anticoagulation treatment. Endoscopy 2000; 32: 109.

29. Christensen M, Hendel HW, Rasmunssen V, Hojgaard L, Schulze S, Rosenberg J. Endoscopic Retrograde Cholangiopancreatografy causes reduced myocardial blood flow. Endoscopy 2002: 797800 .

30. Baillie J. Complications of ERCP, en ERCP and its applications, IM Jacobson, editor. Filadelfia: Lippincott-Raven, 1998. p. 37-54.

31. Andriulli A, Leandro G, Niro G, Mangia A, Festa V, Gambassi G, et al. Medical treatment can diminish pancreatic damages after ERCP: a metaanalysis. Gastrointest Endosc 2000; 51: 1-7.

32. Baillie J. ERCP training: for the few, not for all. Gut 1999; 45: 910.

33. Allison MC, Ramanaden DN, Fouweather MG, Knight Davis DK, Colin-Jones DG. Provision of ERCP services and training in the United Kingdom. Endoscopy 2000; 32: 693-9.

34. Schlup MMT, Williams SM, Barbezat GO. ERCP: a review of technical competency and workload in a small unit. Gastrointest Endosc 1997; 46: 48-52.

35. Yarze JC, Herlihy KJ, Chase MP, Fritz HP. ERCP experience in a community-based, private-practice setting. Am J Gastroenterol 2000; 95: 3006-7.

36. García-Cano Lizcano J, González Martín JA, Pérez Sola A, Morillas Ariño J. Tratamiento endoscópico de la ictericia obstructiva en un hospital de nivel II del Sistema Nacional de Salud. Gastroenterol Hepatol 2001; 24: 287-91.

37. Cotton PB, Williams CB. Practical Gastrointestinal Endoscopy 3rd edition. Londres: Blackwell Scientific Publications, 1990. p. 118.

38. Soehendra N, Binmoeller KF, Seifert H, Scheiber HW. Therapeutic Endoscopy. Color Atlas of Operative Techniques for the Gastrointestinal Tract. Thieme, Stuttgart, 1998. p. 92.

39. Wicks ACB, Robertson GSM, Veitch PS. Structured training and assessment in ERCP has become essential for the Calman era. Gut 1999; 45: 154-6.

40. Cotton PB. How many times have you done this procedure, doctor? Am J Gastroenterol 2002; 97: 522-3.

41. Cotton PB. ERCP is most dangerous for people who need it least. Gastrointest Endosc 2001; 54: 535-6.

42. Luman W, Chan ES-Y. Mathematical model for predicting biliary therapeutic endoscopic retrograde pancreatography (ERCP). Digestive and Liver Disease 2003; 35: 486-92.

43. Taylor AC, Little AF, Hennessy OF, Banting SW, Smith PJ, Desmond PV. Prospective assessment of magnetic resonance cholangiopancreatography for noninvasive imaging of biliary tree. Gastrointest Endosc 2002; 55: 17-22. 


\title{
Complicaciones de la colangiopancreatografía retrógrada endoscópica. Estudio en una unidad pequeña de CPRE
}

\author{
J. García-Cano Lizcano, J. A. González Martín, J. Morillas Ariño y A. Pérez Sola
}

Servicio de Aparato Digestivo. Hospital Virgen de la Luz. Cuenca.

\section{RESUMEN}

Antecedentes y objetivo: la colangiopancreatografía retrógrada endoscópica (CPRE) es un procedimiento consolidado para el drenaje de la vía biliar y pancreática, que, sin embargo, conlleva complicaciones. El número parece ser mayor en los centros que realizan menos de $200 \mathrm{CPRE}$ anuales. No obstante, en ocasiones, la distribución de los recursos sanitarios hace preciso realizar esta técnica en centros con menor número de procedimientos. Presentamos la experiencia de las complicaciones de la CPRE en una unidad pequeña.

Material y métodos: estudio retrospectivo sobre unos datos recogidos de forma prospectiva durante seis años (1997-2002). En este periodo, dos endoscopistas, trabajando conjuntamente, han realizado $507 \mathrm{CPRE}$, lo que corresponde a una media aproximada de 84 procedimientos anuales.

Resultados: en las 507 CPRE se produjeron 55 complicaciones $(10,85 \%)$ y como consecuencia de ellas, cuatro pacientes fallecieron $(0,79 \%)$. Hubo 28 pancreatitis $(5,5 \%), 8$ hemorragias postesfinterotomía $(1,6 \%), 7$ perforaciones bilioduodenales $(1,4 \%), 8$ sepsis de origen biliar $(1,6 \%)$ y otras 4 complicaciones varias. Las CPRE con éxito diagnóstico y terapéutico -cuando se precisó- fueron $418(82,4 \%)$, y presentaron 46 (11\%) complicaciones. Hubo 89 (17,6\%) CPRE con fallo diagnóstico o terapéutico, que presentaron $9(10,11 \%)$ complicaciones ( $p=0,8$ entre ambos grupos). Treinta y cinco (7\%) CPRE fueron exclusivamente diagnósticas, presentando 6 (17\%) complicaciones. Las 187 CPRE realizadas para extraer coledocolitiasis, con $14(7,4 \%)$ complicaciones, fueron el grupo con menor morbilidad $(p=0,04)$.

Conclusiones: la tasa de complicaciones en nuestro centro se encuentra dentro de los rangos publicados. La extracción de coledocolitiasis fue el grupo de CPRE con menos complicaciones. Por su morbilidad, debe valorarse cuidadosamente el riesgo-beneficio de las exploraciones que se prevean exclusivamente diagnósticas.

Palabras clave: Complicaciones de la CPRE.

\section{INTRODUCCIÓN}

La colangiopancreatografía retrógrada endoscópica (CPRE) es una técnica muy eficaz para drenar la vía biliar y pancreática (1). Los métodos de obtención de imágenes con los que se cuenta en la actualidad, especialmente la colangiopancreatografía por resonancia magnética, han convertido a la CPRE en una técnica eminentemente terapéutica.
El acceso al colédoco y al Wirsung, la esfinterotomía, la extracción de coledocolitiasis y la inserción de prótesis en el conducto biliar y pancreático, son los procedimientos endoscópicos digestivos más difíciles (2).

La complejidad de la técnica conlleva una morbilidad que parece ser mayor en los centros que realizan pocas exploraciones. Aunque no hay criterios unánimes aceptados, el número mínimo se ha fijado en 200 CPRE anuales (3), más de una esfinterotomía semanal (4), o, al menos, 40 esfinterotomías al año por endoscopista (5).

Sin embargo, la distribución y el acceso de los pacientes a los recursos sanitarios, pueden crear la necesidad de realizar esta técnica en hospitales en que se espere un volumen anual reducido. Presentamos nuestra experiencia en las complicaciones de la práctica de la CPRE en una unidad pequeña.

\section{MATERIAL Y MÉTODOS}

Durante un periodo de 6 años (1997-2002), dos endoscopistas (JGL y JGM), trabajando de forma conjunta, han realizado 507 CPRE, lo que significa una media aproximada de 84 procedimientos anuales. En exploraciones alternas, cada uno de ellos realizaba la intervención como endoscopista principal y el otro, como ayudante.

Se empleó sedación consciente con meperidina y diazepam o midazolam, administrada por los mismos endoscopistas. En todas las exploraciones, en general, asistió el mismo equipo de enfermería y de auxiliares de clínica. Durante la CPRE se monitorizó la frecuencia cardiaca y la saturación sanguínea y se administró a los pacientes oxígeno con cánula nasal. Las CPRE se realizaron en una sala de radiología con posibilidad de fluoroscopia. Los pacientes dieron su consentimiento para la realización de la prueba tras recibir la información médica oportuna.

Se utilizaron duodenoscopios terapéuticos con un canal de trabajo de 4,2 $\mathrm{mm}$. La canulación de la papila de Vater, esfinterotomía, dilatación, inserción de prótesis y otros procedimientos de la CPRE, se realizaron según técnicas descritas (6-8). Cuando la canulación no pudo conseguirse con 
las cánulas o esfinterotomos habituales, resultó muy útil un esfinterotomo de punta fina con guía de 0,025 pulgadas (9) que se utilizó antes de recurrir a la técnica de precorte.

Cuando no pudo canularse el conducto deseado se consideró fallo diagnóstico. El fallo terapéutico se definió como la falta de tratamiento endoscópico eficaz (en general un drenaje adecuado), cuando era preciso. No se consideraron fallo terapéutico las coledocolitiasis que no se extrajeron totalmente, sí pudo insertarse una prótesis para mantener un drenaje temporal.

El diagnóstico de odditis se realizó por medio de los datos clínicos, analíticos y colangiográficos.

Todos los pacientes a los que se realizó la CPRE estuvieron ingresados, al menos la noche de la intervención. En los días sucesivos, se comprobó si presentaban alguna complicación, que se graduaron según un consenso de 1991 (10).

Los datos relativos a la técnica y a las complicaciones se recogieron de forma prospectiva, aunque el análisis global se ha realizado de forma retrospectiva. Los cálculos estadísticos se realizaron con el programa Rsigma. Se consideró significativa una $\mathrm{p}<0,05$.

\section{RESULTADOS}

En las 507 CPRE se produjeron, en total, $55(10,85 \%)$ complicaciones en 52 pacientes (Tabla I). Hubo 28 $(5,5 \%)$ pancreatitis agudas. La mayoría leves-moderadas. Sólo cuatro precisaron ingreso en UCI. No hubo mortalidad relacionada con las pancreatitis.

Se produjeron $8(1,6 \%)$ hemorragias postesfinterotomía. Todas precisaron esclerosis del punto sangrante y tranfusión sanguínea. En dos de ellas se transfundieron 5 o más concentrados de hematíes, por lo que se consideran graves. Ninguna precisó cirugía ni técnicas hemostásicas angiográficas.
Se produjo una perforación duodenal -lejos del área papilar-en tres pacientes $(0,6 \%)$. Un caso ocurrió en el asa aferente de una gastrectomía Billroth II, otro en un bulbo duodenal estenosado y deformado por enfermedad péptica, y, el tercero, por la perforación de una prótesis biliar plástica de $15 \mathrm{~cm}$ de longitud, insertada en la vía biliar para tratar una estenosis benigna. Todos los pacientes fueron intervenidos y no hubo mortalidad derivada de la perforación.

En tres mujeres la perforación fue en el área papilar $(0,6 \%)$. En una paciente, tras haber realizado la esfinterotomía e intentar canular de nuevo el colédoco -no se había dejado una guía previamente- se produjo una falsa vía, con inyección de contraste en el espacio retroperitoneal. En otra paciente, la perforación se produjo por una esfinterotomía amplia en una papila intradiverticular. Estas dos pacientes evolucionaron satisfactoriamente de las perforaciones con tratamiento médico. La tercera fue en una paciente anciana, con colangitis. La perforación se produjo como consecuencia de un precorte y la enferma falleció.

Un enfermo con una neoplasia compleja del hílio hepático presentó una perforación del árbol biliar, muy probablemente relacionada con la dilatación, previa a la inserción de una prótesis. El paciente desarrolló un absceso abdominal. El estado general aconsejó no realizar ningún tipo de tratamiento agresivo, produciéndose el fallecimiento días después.

Por lo tanto, las perforaciones bilio-duodenales fueron, en total $7(1,4 \%)$.

En un enfermo se produjo la perforación de un divertículo de Zenker no conocido anteriormente. El diagnóstico se realizó de forma inmediata, al observarse con el endoscopio estructuras mediastínicas, y se confirmó con la extravasación de contraste hidrosoluble desde el esófago. El paciente fue intervenido. Se recuperó, finalmente, tras un postoperatorio con múltiples complicaciones.

Tabla I. Complicaciones especificadas en las 507 CPRE. Tres pacientes tuvieron dos complicaciones. En dos se produjo pancreatitis y colangitis. En uno, pancreatitis y hemorragia

\begin{tabular}{|c|c|c|c|c|c|}
\hline Tipo de complicación & Total (\%) & Leves-moderadas & Cirugía & $\begin{array}{l}U \text { UCl } \\
(* *)\end{array}$ & $\begin{array}{l}\text { Exitus } \\
(* * *)\end{array}$ \\
\hline Pancreatitis & $28(5,5 \%)$ & 24 & - & 4 & - \\
\hline Perforación del área papilar & $3(0,6 \%)$ & 2 & - & - & 1 \\
\hline Perforación duodenal & $3(0,6 \%)$ & - & 3 & - & - \\
\hline Perforación biliar & $1(0,2 \%)$ & - & - & - & 1 \\
\hline Perforación divertículo de Zenker & $1(0,2 \%)$ & - & 1 & - & - \\
\hline Hemorragia post esfinterotomía & $8(1,6 \%)$ & $6 *$ & - & - & - \\
\hline Colangitis & $6(1,3 \%)$ & 5 & - & 1 & - \\
\hline Colecistitis & $2(0,4 \%)$ & 1 & - & - & 1 \\
\hline Parada cardiorespiratoria & $1(0,2 \%)$ & - & - & - & 1 \\
\hline Edema agudo de pulmón & $1(0,2 \%)$ & - & - & 1 & - \\
\hline Rotura de prótesis intrapancreática & $1(0,2 \%)$ & - & 1 & - & - \\
\hline$\overline{\text { Total }}$ & $55(10,85 \%)$ & $38 *(7,49 \%)$ & $5(0,98 \%)$ & $6(1,18 \%)$ & $4(0,79 \%$ \\
\hline
\end{tabular}

(*) Aunque no precisaron cirugía, dos pacientes necesitaron transfusión de más de 5 concentrados de hematíes, por lo que la hemorragia se considera grave. Por lo tanto, a la suma del total de gravedad de las complicaciones habría que sumar estas dos hemorragias para llegar a 55 . Los porcentajes están realizados sobre los 507 pacientes. ${ }^{* *}$ ) Pacientes que precisaron ingreso en la Unidad de Cuidados Intensivos (UCI). No se incluyen aquí los pacientes que, después de operados, estuvieron en la UCI.

$(* * *)$ Ninguno de los pacientes que falleció fue intervenido quirúrgicamente ni estuvo ingresado en la UCI. 
En seis $(1,2 \%)$ pacientes se produjeron colangitis. Cinco de ellas fueron secundarias a coledocolitiasis retenidas tras la CPRE, o a prótesis biliares plásticas insertadas en tumores del hílio hepático. Todas evolucionaron satisfactoriamente con tratamiento médico en planta. La colangitis restante ocurrió en un paciente en el que después se diagnosticó una leucemia y precisó ingreso en UCI.

Dos enfermos presentaron colecistitis. Uno de ellos, una paciente con una neoplasia de la cabeza de páncreas, en la que se había insertado una prótesis biliar plástica, falleció. Las sepsis de origen biliar (colangitis y colecistitis) fueron, por lo tanto, $8(1,6 \%)$.

Un paciente anciano, en el que se realizó la CPRE por colangitis, falleció tras presentar una parada cardiorrespiratoria al llegar a su habitación después de la prueba. Esta complicación quizás podría estar relacioanada con la medicación sedante durante el procedimiento endoscópico. Otro paciente, con cardiopatía isquémica, desarrolló horas después de la intervención endoscópica un edema agudo de pulmón cardiogénico. Se recuperó tras pasar diez días en la UCI.

Por último, se produjo la rotura intrapancreática de una prótesis de $12 \mathrm{~cm}$ de longitud. Se había insertado para tratar una fístula pleuro-pancreática en un paciente con pancreatitis crónica. La porción distal de la prótesis quedó en el Wirsung al intentar extraerla, tras comprobar que la fístula se había cerrado. El paciente precisó una pancreatectomía caudal después de intentos infructuosos de extracción endoscópica.

Sólo 17/55 complicaciones fueron graves (31\%), que en la serie total suponen 17/507 (3,3\%) complicaciones severas. La mayoría fueron, pues, leves-moderadas y curaron con tratamiento médico. El fallecimiento se produjo en 4 pacientes $(0,79 \%)$.

Las CPRE se distribuyeron en 8 grupos (Tabla II), según fueran exclusivamente diagnósticas, por el tipo de terapéutica efectuada, o, si se fallaron. Se observa que las $187 / 418(44,7 \%)$ CPRE realizadas para extraer coledocolitiasis, fueron el grupo con menos complicaciones $-14 / 187(7,4 \%)-$, y el único con una morbilidad significativamente menor $(\mathrm{p}=0,04)$ que el resto de la serie.

El grupo de CPRE que no precisó ninguna medida terapéutica (exclusivamente diagnósticas), fue el que tuvo más complicaciones -6/35 (17\%)-. Sin embargo, esta cifra no alcanzó diferencia estadísticamente significativa con el resto de la serie.

Tampoco se encontró diferencia estadística $(\mathrm{p}=0,8)$ entre las $46(11 \%)$ complicaciones de las 418/507 (82,4\%) CPRE con éxito diagnóstico y terapéutico -cuando fue preciso-, y las $9(10,11 \%)$ complicaciones de las 89/507 $(17,6 \%)$ CPRE con fallo diagnóstico o terapéutico.

Se usó la técnica del precorte, de forma global, en 63 $(12,4 \%)$ CPRE. No hubo diferencias en su utilización entre los diferentes grupos. Lógicamente, en las CPRE fallidas, no se consiguió el acceso a la vía biliar. Hubo 8 complicaciones $(12,7 \%)$, que no alcanzan diferencia significativa con respecto a las CPRE en que no se utilizó.
Tabla II. Complicaciones según el resultado de la CPRE. Hubo éxito completo diagnóstico y terapéutico -cuando se necesitó- en 418/507 CPRE (82,4\%). Hubo mortalidad en el grupo de fallo en el acceso a la vía biliar $(1 / 61=1,6 \%)$, en el drenaje tumoral $(2 / 62=3,2 \%)$ y en el tratamiento de la coledocolitiasis $(1 / 187=0,5 \%)$

\begin{tabular}{|c|c|c|c|}
\hline Tipo de procedimiento & $\begin{array}{l}\text { Número de pacientes } \\
\text { en el grupo (\%) }\end{array}$ & $\begin{array}{l}\text { Complicaciones } \\
(\%)\end{array}$ & $\begin{array}{l}\text { Significación } \\
\text { estadistica (1) }\end{array}$ \\
\hline $\begin{array}{l}\text { Fallo en el acceso a } \\
\text { la papila o en la } \\
\text { canulación }\end{array}$ & $61 / 507(12 \%)$ & $6 / 61(9,8 \%)$ & $p=0,7$ \\
\hline $\begin{array}{l}\text { Fallo terapéutico una } \\
\text { vez canulada la papila }\end{array}$ & $28 / 446(6,2 \%)$ & $3 / 28(10,7 \%)$ & $p=0,9$ \\
\hline $\begin{array}{l}\text { Exclusivamente diagnós- } \\
\text { ticas sin necesidad de } \\
\text { terapéutica }\end{array}$ & $35 / 418(8,3 \%)$ & $6 / 35(17 \%)$ & $p=0,2$ \\
\hline $\begin{array}{c}\text { Tratamiento de la coledo- } \\
\text { colitiasis y barro biliar }\end{array}$ & $187 / 418(44,7 \%)$ & $14 / 187(7,4 \%)$ & $p=0,04^{* *}$ \\
\hline Drenaje biliar tumoral & $72 / 418(17,22 \%)$ & $10 / 72(13,8 \%)$ & $p=0,4$ \\
\hline $\begin{array}{l}\text { Esfinterotomía biliar por } \\
\text { coledocolitiasis migradas } \\
\text { y odditis }\end{array}$ & $83 / 418(19,8 \%)$ & $12 / 83(14,45 \%)$ & $p=0,2$ \\
\hline $\begin{array}{l}\text { Tratamiento del síndrome } \\
\text { de Mirizzi y otras } \\
\text { estenosis benignas }\end{array}$ & $35 / 418(8,3 \%)$ & $3 / 35(8,5 \%)$ & $p=0,6$ \\
\hline Terapéutica pancreática & $6 / 418(1,4 \%)$ & $1 / 6(16,6 \%)$ & $p=0,6$ \\
\hline Total & 507 & $55 / 507(10,85 \%)$ & \\
\hline
\end{tabular}

\section{DISCUSIÓN}

La CPRE es la técnica más difícil de la endoscopia digestiva. Las complicaciones ocurren, aproximadamente, en un 10\%, y, la mortalidad, es de alrededor del 1\% (2). Este es el rango en el que suelen oscilar las cifras de la gran cantidad de series que se han publicado (Tabla III). Los datos de nuestro estudio, con un $10,85 \%$ de complicaciones y una mortalidad del $0,79 \%$, se encuentran también, en términos generales, en torno a las cifras previamente comunicadas.

Las cuatro complicaciones típicas de la CPRE son la pancreatitis aguda, la hemorragia postesfinterotomía, la sepsis de origen biliar (colangitis y colecistitis) y la perforación, tanto del área papilar, por la esfinterotomía, como del duodeno por el endoscopio o las prótesis biliares. En nuestro estudio, hemos encontrado un 5,5\% de pancreatitis, $1,6 \%$ de hemorragias, $1,4 \%$ de perforaciones bilioduodenales y un 1,6\% de sepsis biliares. Estas cifras son también equiparables a las de otros estudios (Tabla IV). Existen, además, otros efectos adversos más raros y menos típicos de la CPRE. En nuestro caso, se produjo la perforación de un divertículo de Zenker, la rotura intrapancreática de una prótesis plástica, una parada cardiorrespiratoria -quizás relacionada con la sedación- y un edema agudo de pulmón, horas después de la CPRE. He- 
Tabla III. Morbilidad y mortalidad en algunas series generales de CPRE

\begin{tabular}{|c|c|c|c|c|c|c|c|}
\hline Autor (referencia) & Año & País & $N^{\circ}$ hospitales & $N^{\circ}$ CPRE & \% complicaciones & $\%$ mortalidad & Observaciones \\
\hline$\overline{\text { Zimmon (11) }}$ & 1975 & EE.UU. & Un solo centro & 300 & 5 & 0 & $\begin{array}{l}\text { Sólo CPRE } \\
\text { diagnósticas }\end{array}$ \\
\hline Bilbao (12) & 1976 & EE.UU. & Multicéntrico & 10.435 & 3 & 0,2 & $\begin{array}{l}\text { Sólo CPRE } \\
\text { diagnósticas }\end{array}$ \\
\hline Soehendra (13) & 1977 & Alemania & Un solo centro & 604 & 2 & 0 & $\begin{array}{l}\text { Sólo CPRE } \\
\text { diagnósticas }\end{array}$ \\
\hline Moreira (14) & 1982 & España & Un solo centro & 500 & 2,8 & 0,2 & $\begin{array}{l}\text { La mayoría sólo } \\
\text { diagnósticas }\end{array}$ \\
\hline Elizondo (15) & 1989 & México & Un solo centro & 500 & 5,6 & 0,8 & \\
\hline Varios autores (10) & 1991 & Varios países & Multicéntrico & 7.729 & 8,2 & 1,3 & $\begin{array}{l}\text { Sólo CPRE con } \\
\text { esfinterotomía }\end{array}$ \\
\hline Freeman (4) & 1996 & $\begin{array}{l}\text { EE.UU. y } \\
\text { Canadá }\end{array}$ & Multicéntrico & 2.347 & 9,8 & 0,4 & $\begin{array}{l}\text { Sólo CPRE con } \\
\text { esfinterotomía }\end{array}$ \\
\hline Anh (16) & 1997 & Vietnam & Un solo centro & 318 & 7,2 & 0,3 & \\
\hline Loperfido (3) & 1998 & Italia & Multicéntrico & 2.769 & 4 & 0,4 & \\
\hline Ciriza (17) & 1999 & España & Un solo centro & 425 & 8,6 & 1,6 & \\
\hline Halme (18) & 1999 & Finlandia & Un solo centro & 813 & 9,1 & 0,9 & $\begin{array}{l}\text { Complicaciones sólo } \\
\text { de las esfinterotomías }\end{array}$ \\
\hline Zinsser (19) & 1999 & Alemania & Un solo centro & 2.820 & 7,9 & 0,1 & \\
\hline Rabenstein (5) & 1999 & Alemania & Un solo centro & 1.335 & 7,3 & 0,5 & $\begin{array}{l}\text { Sólo CPRE con } \\
\text { esfinterotomía }\end{array}$ \\
\hline Mala (20) & 2000 & Noruega & Un solo centro & 567 & 1,2 & 0,8 & $\begin{array}{l}\text { Sólo se indican } \\
\text { complicaciones severas }\end{array}$ \\
\hline Gómez-Ponce (21) & 2000 & Perú & Un solo centro & 202 & 5,9 & 0 & \\
\hline Tzovaras (22) & 2000 & Australia & Un solo centro & 372 & 4,3 & 1,3 & \\
\hline Masci (23) & 2001 & Italia & Multicéntrico & 2.462 & 4,95 & 0,12 & \\
\hline Farrell (24) & 2002 & Irlanda & Un solo centro & 1.758 & 3,5 & 0,35 & \\
\hline Vandervoort (25) & 2002 & EE.UU. & Un solo centro & 1.223 & 11,2 & 0,16 & \\
\hline Suissa (26) & 2002 & Israel & Un solo centro & 722 & 10,5 & 0,5 & \\
\hline Barthet (27) & 2002 & Francia & Un solo centro & 658 & 7,7 & 0,9 & $\begin{array}{l}\text { Sólo CPRE con } \\
\text { esfinterotomía }\end{array}$ \\
\hline García-Cano (*) & 2003 & España & Un solo centro & 507 & 10,85 & 0,79 & \\
\hline
\end{tabular}

${ }^{*}$ ) Se incluye la serie objeto de este estudio.

Tabla IV. Complicaciones específicas de la CPRE en series generales prospectivas. Es difícil hacer comparaciones entre ellas. En algunas sólo se hace referencia a las CPRE con esfinterotomía. En la serie de Loperfido no se señalan las complicaciones leves (principalmente pancreatitis). Las complicaciones individuales no suman el total, porque no se han reflejado otras complicaciones menos típicas y frecuentes de la CPRE, como las cardiopulmonares

\begin{tabular}{|c|c|c|c|c|c|c|c|c|}
\hline Autor (referencia) & Año & $\begin{array}{c}\text { Complicaciones/ } \\
\text { pacientes }\end{array}$ & Pancreatitis & Hemorragia & $\begin{array}{l}\text { Sepsis de origen } \\
\text { biliar (1) }\end{array}$ & Perforación & Mortalidad & Observaciones \\
\hline Freeman (4) & 1996 & $229 / 2.347(9,8 \%)$ & $127(5,4 \%)$ & $48(2 \%)$ & $35(1,5 \%)$ & $8(0,3 \%)$ & $10(0,4 \%)$ & Sólo esfinterotomías \\
\hline Loperfido (3) & 1998 & $111 / 2.769(4 \%)$ & $36(1,3 \%)$ & $21(0,76 \%)$ & $24(0,87 \%)$ & $16(0,58 \%)$ & $11(0,4 \%)$ & $\begin{array}{l}\text { Serie global de } \\
\text { CPRE, se excluyen } \\
\text { complicaciones leves }\end{array}$ \\
\hline Rabenstein (28) & 2000 & $33 / 438(7,5 \%)$ & $19(4,3 \%)$ & $10(2,3 \%)$ & $4(0,9 \%)$ & 0 & $2(0,5 \%)$ & Sólo esfinterotomías \\
\hline Masci (23) & 2001 & $121 / 2.444(4,95 \%)$ & $44(1,8 \%)$ & $30(1,13 \%)$ & $19(0,77 \%)$ & $16(0,65 \%)$ & $3(0,12 \%)$ & Serie global de CPRE \\
\hline Barthet (27) & 2002 & $51 / 658(7,7 \%)$ & $23(3,5 \%)$ & $8(1,2 \%)$ & $8(1,2 \%)$ & $12(1,8 \%)$ & $6(0,9 \%)$ & $\begin{array}{l}\text { Datos sólo de las es- } \\
\text { finterotomías de la } \\
\text { serie global anterior }\end{array}$ \\
\hline
\end{tabular}

(1) La sepsis de origen biliar corresponde a colangitis y colecistitis

mos considerado relacionada esta complicación con la intervención endoscópica, porque está descrita la reducción del flujo sanguíneo miocárdico durante la CPRE (29).

De todos modos, quizás, el porcentaje de complicaciones reales sea mayor del que aparece en las series. La gran mayoría de los estudios definen las complicaciones de la CPRE según un consenso de 1991 (10). Según estos criterios, $\mathrm{y}$, por ejemplo, con respecto a la hemorragia postesfinterotomía, comienza a considerarse complicación leve el descenso de la hemoglobina superior a 2 gra- 
mos. El sangrado endoscópico durante el procedimiento, si no hay descenso de las cifras hemáticas, no se considera como complicación. Sin embargo, la utilización de medidas hemostásicas para detener una hemorragia, puede aumentar enormemente la complejidad de la CPRE, aunque no quede reflejada como complicación.

Con respecto a la pancreatitis aguda, la definición habitual es la elevación de la amilasa, al menos tres veces, por encima del valor normal, durante más de 24 horas, junto con dolor abdominal, que requiere estancia hospitalaria. Si la CPRE se realiza en régimen ambulatorio y la serie es retrospectiva, los pacientes pueden tener ligero dolor abdominal en su domicilio, que realmente corresponda a una pancreatitis aguda leve, que queda sin diagnosticar y, por lo tanto, sin comunicar. Comenta Baillie (30), que en un estudio prospectivo realizado en su centro, por medio de una encuesta telefónica, en los 30 días siguientes a la CPRE, aumentó la tasa de complicaciones en un $50 \%$. La pancreatitis aguda fue la complicación descubierta con más frecuencia.

Además, las series prospectivas multicéntricas, como la de Masci (23), tienen menos complicaciones que las de un sólo centro, como, por ejemplo, la de Vandervoort (25). Quizás, en las multicéntricas, puedan dejar de considerarse complicaciones leves, que, como en todas las series, son las más frecuentes.

Otro aspecto que debe tenerse en cuenta al analizar estos estudios, es, lo que podríamos llamar, la filosofía para imputarse complicaciones. Por ejemplo, en todos aquellos trabajos en que se estudian fármacos en la reducción de la pancreatitis postCPRE, la frecuencia de esta complicación, en las series control, es mayor que en los estudios habituales (31).

La CPRE es un procedimiento muy complejo, que, lógicamente, no pueden realizar todos los endoscopistas (32). Es necesaria, no sólo una larga curva de aprendizaje, sino, también, un mantenimiento de la destreza adquirida, por medio de la realización constante y habitual de exploraciones. Lo ideal sería que menos endoscopistas realizaran más CPRE (2). Sin embargo, frecuentemente, y tal como ocurre en nuestro centro, la distribución de los recursos sanitarios hace preciso que esta técnica se lleve a cabo en hospitales que no llegan a las $200 \mathrm{CPRE}$ por año (33).
La dedicación continua y habitual de pocas personas, en un centro pequeño, puede conseguir unos resultados aceptables en la CPRE (34-36). En nuestra unidad, los dos médicos que realizan esta técnica asisten a todas las pruebas. En la mitad de ellas, como endoscopista principal, y, en la otra mitad, como ayudante. Este concepto, que está claramente definido en las intervenciones quirúrgicas, falta en las intervenciones endoscópicas. Pensamos que la complejidad del intervencionismo endoscópico biliopancreático es tal, que, además de contar con un personal de enfermería cualificado -que puede marcar la diferencia entre el éxito y el fracaso (37)-, sería aconsejable que hubiera habitualmente, al menos, dos médicos endoscopistas realizando las pruebas. El material adecuado y en buen uso es otro condicionante del éxito (38).

Las CPRE realizadas con éxito tuvieron complicaciones similares a las fallidas. Es fácil de entender. Los intentos infructuosos repetidos para canular la papila producen pancreatitis. Más grave aún si se utiliza el precorte de forma ineficaz. Una vez realizada la colangiografía, la imposibilidad de drenar adecuadamente una vía biliar obstruída, conlleva una colangitis. Por tanto, cuando un endoscopista se enfrenta a una CPRE, debe tener las mayores posibilidades de conseguir los resultados deseados. Para ello debe procurarse una continua mejora técnica -superando las tasas de éxito mínimas aceptadas del $80 \%$ (39)- y autocrítica (40).

Por último, el único grupo, en nuestro estudio, con una morbilidad significativamente menor fue el del tratamiento de la coledocolitiasis. Dato similar al comunicado por Freeman (4) en la extracción de litiasis coledocianas, en pacientes a los que se les realizó una colecistectomía laparoscópica. Las CPRE diagnósticas tuvieron, por tanto, más complicaciones que aquellas en que se extrajeron coledocolitiasis. Esta paradoja subraya la necesidad de evitar complicaciones en el paciente que, quizás, menos necesita la CPRE (41). Cuando se prevee que la prueba pudiera ser exclusivamente diagnóstica (42), debe valorarse muy cuidadosamente el riesgo-beneficio que pueda aportar el procedimiento endoscópico. En estas circunstancias, quizás, actualmente, la colangiopancreatografía por resonancia magnética es el método de elección al que se debería recurrir (43). 